\title{
Determinants of web-user satisfaction: using technology acceptance model
}

\author{
Zaitul ${ }^{1}$, Fanny Ramadhani ${ }^{2}$, and Desi Ilona $^{3 *}$ \\ ${ }^{1}$ Economics Faculty, Universitas Bung Hatta, Padang, Indonesia \\ ${ }^{2}$ Master Student, Information Engineering, Universitas Sumatra Utara, Medan, Indonesia \\ ${ }^{3}$ Economics Faculty, Universitas Putra Indonesia YPTK, Padang, Indonesia
}

\begin{abstract}
This study investigates the determinant of web-user satisfaction. User satisfaction is successful measurement for IT implementation. Technology Acceptance Model and Theory of Plan Behaviour are used to underpin the relationship. Two variables are applied as determinants of webuser satisfaction: perceived usefulness and perceived ease of use. Students from four faculties are used as research object and questioner were distributed online by giving URL-Link through WhatsApp. 53 Students filled the questioners. Smart-PLS use to analyse data. The finding show that perceived ease of use has a positive relationship with user satisfaction. However, perceived usefulness does not have a significant relationship with user satisfaction. This study has a practical and theoretical implication. Practically, the finding can be used to formulate the future university website development. Theoretically, this study contributes to the Technology Acceptance Model and Theory of Plan Behaviour.
\end{abstract}

\section{Introduction}

Information technology is being widely deployed throughout industry, education, government and other institution[1]. In fact, the use of information technology in education institutions have been growing recently, such as higher education institution[2]. Refernce[1] argue that IT services for satisfying personal needs are growing at a rate that will have substantial influence in the information infrastructure. The use of IT has been widely in almost of all management functions, including academics, financial, student affair and etc. For example, Universitas Bung Hatta has been developing a decade ago. It was started in 2005 when University used the Microsoft access as platform. Five years ahead, this university applied the html as platform and it has been moving forward using more advance html platform to satisfy all university's stakeholders. End-user satisfaction is critical to information system success[1].

There are bundle of studies investigating the system-user satisfaction, see for example, [1], [3], [4], [5], [6], [7] and [8]. [1] study about key success factors affecting of information technology through user's behavioral perspective. They found that perceived ease of use, and perceived usefulness are the most significant factors affecting an intention to use IT service and user-satisfaction. Whereas, refence[3] investigate nine variables: perceived attitude of

*Corresponding author email: desiilona@upiyptk.ac.id 
top management toward the project, perceived usefulness, user expectation user experience, ease of use, user skills and user involvement in system development, organizational support, and user attitude toward information system. reference[3] conclude that the most significant variables affecting the end user satisfaction is involvement, perceived usefulness, user experience, organization support, and user attitude toward the IS. [4] validate the end user computing satisfaction instrument developed by [6] and conclude the instrument had its psychometric stability when tested for users of enterprise resources planning. Further, reference[5] study on end user information systems satisfaction formation and conclude that equitable work performance fulfillment and equitable relatedness fulfillment are significant factors affecting satisfaction of end users. Thus, reference[7] investigate the end user satisfaction of e-government services using quality-in-use satisfaction with advanced traveler information systems (ATIS). Finally, reference[8] review the previous studies that investigating factors affecting the system-user satisfaction.

To date, many attempts have been made to study factors affecting the IT user satisfaction. However, there is a lack of studies investigating the subject matters using the stakeholders of higher education institution (HEI). As mention before, HEI has been using the IT largely [2], but previous researchers paid less attention, especially study on user satisfaction. Therefore, there is a desired need to investigate the user-satisfaction in the context of HEI, such as University. Perceive ease of use is one of factor affecting the system user satisfaction [1][3] and [8]. End-user satisfaction is also determined by Perceived usefulness (i.e. [1] ). However, the effect of these variables on end-user satisfaction is not conclusive. Therefore, this study aims to investigate the effect of perceived ease of use and perceived usefulness on end user satisfaction. This paper is organized as follow: first session discusses about background of study. Second session is talking about methods and followed by result and discussion. Final session is conclusion and recommendation.

\section{Methods}

Students in faculty of economics, industrial technology, education, and law are used as research object. These students were taken due to their experiences using the university's website.primary data used in this research and questioners were distributed to them through WhatsApp by sending the URL-link. There are two type of variables; dependent variable (website user-satisfaction), and independent variable (perceived ease of use and perceived usefulness). The end-user satisfaction (SAT) is measured by four items [7]. Example of item is "I felt very confident using this website". Further, perceived ease of use (PEU) and perceived usefulness (PU) using 7 and 4 items respectively. The instrument of PEU and PU were adopted from [7]. Example of item for PEU and PU are "I thought the system is easy to use" and "I found the information in website to be very useful". To measure the respondents' perception on the survey question, five-point Likert scale was applied. Data analyses was conducted using a software of Smart-PLS 2.0. SEM-PLSis a second-generation regression technique for complex causal modeling. This technique is also known as variance-based structural equation modeling [9]. There are two kinds of analysis using PLS: measurement model and structural model [10]. To assess the measurement model, there are four criteria[11]: outer loading, internal consistency, convergent validity and discriminant validity. Further, the structural model has two criteria: predictive power and predictive relevance [11].

\section{Result and discussion}


There are 53 students participating in this study. Demography data is shown in Table 1. Male students involved are 11 students or $20.75 \%$ and the rest is female $(79.25 \%)$. Students with age of 20 years old are 11 or $20.75 \%$, followed by 21 years old student $(47.17 \%), 22$ years old $(28.30 \%)$ and more than 22 years old $(3.77 \%)$. 39 Students are from faculty of economics (73.58\%), education (18.87\%), law (5.66\%), and Technology industry (1.89\%).

Table 1. Demographic Analysis

\begin{tabular}{|c|c|c|c|}
\hline Demographic & Category & Number & Percentage \\
\hline \multirow{3}{*}{ Gender } & Male & 11 & 20.75 \\
\cline { 2 - 4 } & Female & 42 & 79.25 \\
\hline \multirow{4}{*}{ Age } & 20 years & 11 & 20.75 \\
\cline { 2 - 4 } & 21 years & 25 & 47.17 \\
\cline { 2 - 4 } & 22 years & 15 & 28.30 \\
\cline { 2 - 4 } & $>22$ years & 2 & 3.77 \\
\hline \multirow{4}{*}{ Faculty } & Economics & 39 & 73.58 \\
\cline { 2 - 4 } & Education & 10 & 18.87 \\
\cline { 2 - 4 } & Law & 3 & 5.66 \\
\cline { 2 - 4 } & Technology Industry & 1 & 1.89 \\
\cline { 2 - 4 } & & & \\
\hline
\end{tabular}

\subsection{Analysis of Measurement model}

The final result for measurement model is demonstrated in Table 2. However, the first analysis of measurement model show that several outer loadings from three constructs are not valid due to the lower outer loading (less than 0.6)[12]. Therefore, non-valid items were excluded from analysis: one item for end-user satisfaction (item 3), and three items for Perceived ease of use (item 3,4, and 6). Having deleted all non-valid items, the algorithmanalysis was conducted again and the result show that all items have a loading greater than 0.6 for all constructs.the second criteria for measurement model is internal consistency. To see the internal consistency, Composite reliability (CR) and Cronbach Alpha (CA) are applied and the result show that the value of CR and CA for all construct are greater than 0.70 . Third criteria of measurement model are the convergent validity that use AVE and the result show that the value of AVE is greater than 0.50 .

Table 2. Measurement Model

\begin{tabular}{|c|c|c|c|c|c|}
\hline Construct & Item & Loadings & CA & CR & AVE \\
\hline \multirow{3}{*}{ SAT } & sat_1 & 0.863 & \multirow{3}{*}{0.881} & \multirow{3}{*}{0.926} & \multirow{3}{*}{0.806} \\
\hline & sat_2 & 0.927 & & & \\
\hline & sat_4 & 0.903 & & & \\
\hline \multirow{4}{*}{ PEU } & peu_1 & 0.923 & \multirow{4}{*}{0.826} & \multirow{4}{*}{0.886} & \multirow{4}{*}{0.662} \\
\hline & peu_2 & 0.864 & & & \\
\hline & peu_5 & 0.698 & & & \\
\hline & peu_7 & 0.749 & & & \\
\hline \multirow{4}{*}{ PU } & pu_1 & 0.910 & \multirow{4}{*}{0.938} & \multirow{4}{*}{0.926} & \multirow{4}{*}{0.844} \\
\hline & pu_2 & 0.944 & & & \\
\hline & pu_3 & 0.914 & & & \\
\hline & $\mathrm{pu} 4$ & 0.908 & & & \\
\hline
\end{tabular}

The final criteria of measurement model (using Fornell-Lacker criterion) also indicate a good measurement model (see Table 3). The correlation coefficient was created through 
square root of the AVE (bold number). Further, this value is compared to coefficient of correlation with other construct. For example, square root of SAT's AVE (0.898) is compared to 0.864 and 0.765 . if the square root of AVE is greater than coefficient correlation with other construct and it can be concluded that the measurement model for SAT is adequate. Therefore, it can conclude that all constructs have a good discriminant validity.

Table 3. Fornell-Lacker Criterion

\begin{tabular}{|c|c|c|c|}
\hline Construct & SAT & PEU & PU \\
\hline SAT & $\mathbf{0 . 8 9 8}$ & & \\
\hline PEU & 0.864 & $\mathbf{0 . 8 1 4}$ & \\
\hline PU & 0.765 & 0.635 & $\mathbf{0 . 9 1 9}$ \\
\hline
\end{tabular}

\subsection{Analysis of structural model}

Second analysis is structural model. The result of structural model could be seen in Table 4 and Figure 2. To assess the structural model, there are two criterias[11] : predictive relevance and predictive power. The former use Q-square and the value must be more than zero. Whereas, the later apply the R-square and higher $\mathrm{R}$ square is required. The significance of structural path coefficient is used to see any significant relationship. The overall explanatory power (R-square) indicate that the model account for $58.7 \%$ for user satisfaction. In addition, the second requirement is Q-square and the result show that the Q-square (0.450) satisfied the cut off value $(>0.00)$. thus, it can conclude that the model achieve the predictive validity [10]. The effect of perceived usefulness on user satisfaction is not significant due to its $t$ value is less than $1.65(\alpha<10 \%)$. However, perceived ease of use has a significant relationship with user satisfaction. The higher the perceived ease of use, the higher the user satisfaction.

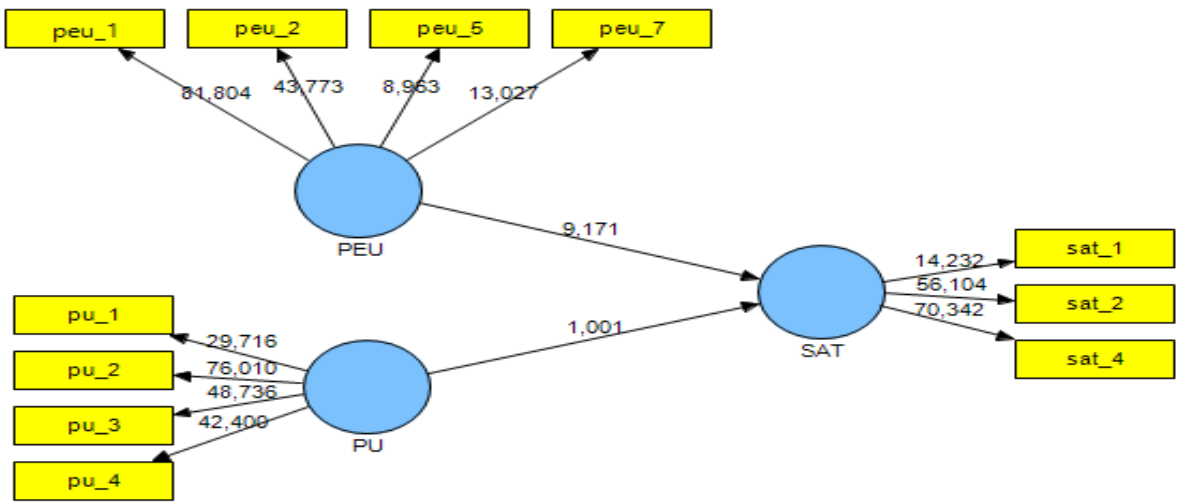

Fig 2. Structural model

Table 4. Structural Model Analysis

\begin{tabular}{|c|c|c|}
\hline Endogenous Construct & R-Squared & Q-Squared \\
\hline SAT & 0.587 & 0.450 \\
\hline Relation & Path Coefficient & T Value \\
\hline PU -> SAT & -0.104 & 1.001 \\
\hline PEU -> SAT & 0.855 & $9.171^{* * *}$ \\
\hline
\end{tabular}

Note; $* * *$ significant at $1 \%$

The insignificant effect of perceived usefulness on user satisfaction is not consistent with the finding of [7][1] and suggestion of [8]. Further, the significant effect of perceived ease of 
use on user satisfaction is aligned with [3], [7], [8], [1]. If university intent to increase a website user satisfaction: (i) the website must be easy to use, (ii) there is a technical support to use it, (iii) no need to learn a lot thing before using it, and (iv) easy to learn to use the website quickly.

\section{Conclusion and Recommendation}

User satisfaction is a measurement of IT implementationsuccess. There are few theories used to understand why user satisfy or not, such as Technology acceptance model[14]. From Technology acceptance model (TAM), perceived ease of use and perceived usefulness. Theory of plan behaviour (TPB) [15] predict that these two variables influence the intention to use and finally user satisfaction. This study found that there is a significant relationship between user satisfaction and perceived ease of use. The finding from this study provide a new understanding of website user satisfaction from student's perspective and contribute to the TAM and TPB in the sense that website university user (student) satisfaction also can be explained by these two theories. Practically, the university could increase the perceived ease of use to website if they intent to increase user satisfaction. Finally, a number of important limitation need to be considered. First, this study uses the university students as respondent. Second, this study only applied two variables as factors affecting the user satisfaction. Finally, this study utilized a direct effect of these variables on user satisfaction. This study has thrown up many questions in need of further investigation. First, future researcher can study the user satisfaction but use the different respondents, such as lecturer or other university's stakeholders. Second, the future study also can use other independent variables suggested by previous researcher, such as coverage, customize access, and etc. [7]. Finally, future investigation also can consider the role of mediating or moderating variables.

\section{References}

1. Y. Liu, Y. Chen, C. Zhou, international conference (2006).

2. M. Fusilier, S. Durlabhji, Campus-Wide Inf. Syst., 22, 4 (2005)

3. M. Adam Mahmood, J. M. Burn, L. A. Gemoets, C. Jacquez, Int. J. Hum. Comput. Stud., 52, 4 (2000) .

4. T. M. Somers, K. Nelson, J. Karimi, Decis. Sci., 34, 3 (2003)

5. A. Au, E. W. T. Ngai, T. C. E. Cheng, MIS Q.,32, 1 (2008).

6. W. J. Doll, W. Xia, G. Torkzadeh,MIS Q., 18, 4 (1994)

7. T. A. Horan, T. Abhichandani, R. Rayalu, Conference on System Sciences (2006)

8. M. Hidayat, W. W. Winarno, D. Adhipta, Seminar Nasional Teknologi Informasi dan Multimedia(2014)

9. J. F. Hair, C. M. Ringle, M. Sarstedt, J. Mark. Theory Pract., 19, 2 (2011)

10. J. F. Hair, G. T. M. Hult, C. M. Ringle, M. Sarstedt, A Primer on Partial Least Squares Structural Equation Modeling (PLS-SEM), (Thousand Oaks: Sage, 2013).

11. V. E. Vinzi, W. W. Chin, J. Henseler, H. Wang, (Springer, 2010).

12. J. F. Hair, C. William, B. J. Babin, R. E. Anderson, Multivariate Data Analysis, $7^{\text {th }}$ (Pearson Education Limited, 2014)

13. Y. Liu, Y. Chen, C. Zhou, international conference (2006).

14. F. D. Davis, Int. J. Man-Machine Stud., 38 (1993)

15. I. Ajzen, Organ. Behav. Hum. Decis. Proccess, 50 (1991) 